\title{
Glucose and lipid lowering effects of Enhydra fluctuans extract in cadmium treated normal and type-2 diabetic model rats
}

Mohammad Nazmul Hasan ${ }^{1 \dagger}$, Farah Sabrin ${ }^{1 \dagger}$, Begum Rokeya ${ }^{2}$, Md Shahinul Haque Khan ${ }^{3}$, Mahtab Uddin Ahmed ${ }^{4}$, Abel Matondo ${ }^{5}$, Md Morsaline Billah ${ }^{6}$ and Salima Akter ${ }^{7 *}$ (D)

\begin{abstract}
Background: Recent epidemiological and experimental studies suggest that cadmium and diabetes-related hyperglycemia may act synergistically to worsen metabolic regulation. The present study aims to evaluate the potential effects of Enhydra fluctuans extract in diabetes and dyslipidemia in cadmium $\left(\mathrm{CdCl}_{2}\right)$ induced- normal and type 2 diabetic model rats.

Method: Forty-eight Long-Evans rats were divided equally into the following six groups: Normal Control (N-C), Normal treated with $\mathrm{CdCl}_{2}(\mathrm{~N}-\mathrm{Cd})$, Normal treated with plant extract $(\mathrm{N}-\mathrm{P})$, Normal treated with both plant extract and $\mathrm{CdCl}_{2}$ (N-PCd), Diabetic treated with plant extract (DM-P) and Diabetic treated with both plant extract and $\mathrm{CdCl} 2$ (DM-PCd). Blood glucose and other biochemical parameters were estimated by the enzymatic colorimetric method. Histological analysis of liver and heart was done by the hematoxylin-eosin ( $H$ \& E) method.

Results: Twenty-one days treatment of $E$. fluctuans extracts at a dose of $200 \mathrm{mg} / \mathrm{kg}$ significantly reduced blood glucose level in N-PCd and DM-PCd $(p<0.05)$, and DM-P $(p<0.01)$ group. The plant extract had no direct effects on total blood lipids but, it had beneficial effects on TG/HDL-C ratio in N-P and DM-PCd groups $(p<0.05)$. Cd induction significantly reduced body weight $[(\mathrm{N}-\mathrm{Cd}, \mathrm{N}-\mathrm{PCd}, \mathrm{DM}-\mathrm{PCd})(\mathrm{p}<0.01)]$, and induced liver $[\mathrm{N}-\mathrm{Cd}(\mathrm{p}<0.05)$, $\mathrm{N}-\mathrm{PCd}, p<0.001]$ and renal impairment $[\mathrm{N}-\mathrm{Cd}(\mathrm{p}<0.05)]$. In bi-variate association, a significant positive correlation between serum glucose and SGPT $(p<0.05)$ as well as SGPT and TG/HDL ratio $(p=0.019)$ was found in DM-P and in the merged group. The histology of liver and heart showed severe damages including inflammation, nuclear pyknosis, loss of myocardial fibers, necrosis and fibrosis in the Cd treated groups compared to plant treated groups.

Conclusion: E. fluctuans seems to have potent antihyperglycemic effects in diabetes and $\mathrm{Cd}$ toxicity along with partial antidyslipidemic properties in euglycemic and diabetic rats. Our study suggests a novel oral antihyperglycemic agent in the present environmental context.
\end{abstract}

Keywords: Hyperglycemia, Dyslipidemia, Type 2 diabetes, Cadmium toxicity, Enhydra fluctuans

*Correspondence: salima_2015@buhs.ac.bd

${ }^{\dagger}$ Mohammad Nazmul Hasan and Farah Sabrin contributed equally to this

work.

7Department of Medical Biotechnology, Bangladesh University of Health

Sciences, Dhaka 1216, Bangladesh

Full list of author information is available at the end of the article

(c) The Author(s). 2019 Open Access This article is distributed under the terms of the Creative Commons Attribution 4.0 International License (http://creativecommons.org/licenses/by/4.0/), which permits unrestricted use, distribution, and reproduction in any medium, provided you give appropriate credit to the original author(s) and the source, provide a link to the Creative Commons license, and indicate if changes were made. The Creative Commons Public Domain Dedication waiver (http://creativecommons.org/publicdomain/zero/1.0/) applies to the data made available in this article, unless otherwise stated. 


\section{Background}

Diabetes mellitus (DM) is a chronic metabolic disorder characterized by elevated levels of glucose in the blood. It is one of the rapid rising health challenges in middleand low-income countries. According to the WHO, the worldwide prevalence of DM in adults was estimated to $4.7 \%$ in 1980 , and $8.5 \%$ in 2014 [1, 2]. In 2016, 1.6 million diabetes-associated deaths were recorded, and currently 422 million people live with diabetes related complications characterized by microvascular (viz. retinopathy, neuropathy and nephropathy) or macrovascular (viz. myocardial infarction, heart failure and stroke) diseases resulting from chronic exposure to high glucose and altered blood lipids [3, 4]. Predominant factors like sedentary high-stress lifestyle and poor diet including high glycemic and trans-fat with low-fiber and -phytonutrients contribute to the epidemic of diabetes [5]. Moreover, the increasing burden of environmental toxins, including persistent organic pollutants and heavy metals, can no longer be ignored as a key etiologic factors of this condition $[6,7]$.

Among the heavy metals, cadmium is the most abundant environmental pollutant, which comes from industrial wastes, cigarette smoking, electroplating, plastic products, pigments, phosphate fertilizer, battery manufactures and pesticides [8]. It has a long half-life that disperses in the soil and persists for decades. Therefore, $\mathrm{Cd}$ can easily enter into the food chain or efficiently transfer to plants [9]. This toxic heavy metal has many adverse health effects [10] and studies have suggested that $\mathrm{Cd}$ induced different types of cancers [11, 12], liver- and renal dysfunction [13], diabetes and cardiovascular diseases [14]. In diabetes, it exacerbates beta cell dysfunction and studies showed varied results [15-17]. In the liver, subchronic $\mathrm{Cd}$ exposure has been shown to increase the activity of enzymes responsible for gluconeogenesis and altered lipid metabolism [18]. Also in the kidney it exacerbates renal failure, and synergistic action has been demonstrated between $\mathrm{Cd}$ induced renal dysfunction and diabetes $[19,20]$.

Currently, the available therapy for diabetes comprises insulin and various oral antidiabetic agents namely thiazolidinediones, sulfonylureas and $\alpha$-glucosidase inhibitors. However, most oral antidiabetic agents have their own limitations and adverse side effects [21-23]. To overcome these limitations, a great attention has been focused on a number of potential molecular targets. Recently, plantderived extracts or compounds were evaluated to have antidiabetic targets such as $\alpha$-glucosidase, $\alpha$-amylase, DPP-4, PPAR- $\gamma$, PTP1B and GLUT4 [24]. Hence, antidiabetic drug discovery has altered its focus to natural medicinal plant sources due to nominal side effects $[25,26]$.

In this study, we evaluated Enhydra fluctuans (Family: Asteraceae), a trailing marsh herb, commonly known as
'Helencha' in Bangladesh. The plant contains various phytochemical compounds such as flavonoids, alkaloids, saponins, tannins, phenols and carbohydrates [27, 28]. The hydrophytes are capable of removing the majority of pollutants particularly heavy metals from wastewater by sorption, sedimentation and assimilation processes [29]. In ethnopharmacology, E. fluctuans has been well studied as a CNS depressant, analgesic, anticancer, hepatoprotective and anthelmintic agent. [27, 30, 31]. However, there is no experimental evidence regarding the effects of E. fluctuans plants in hyperglycemia and hyperdyslipidemia. Some traditional medicine practitioner's use E. fluctuans as an antidiabetic plant in tribal populations [32]. Therefore, it was hypothesized that E. fluctuans may reduce blood sugar and lipids levels, and has the ability to retain its effect in heavy metal $(\mathrm{Cd})$ toxicity. In this context, we investigated the antidiabetic and antidyslipidemic effects of E. fluctuans extract in Cd treated normal and type 2 diabetic rat models, and explored whether the plant could protect $\mathrm{Cd}$ and diabetes related complications.

\section{Methods}

\section{Chemicals and reagents}

Streptozotocin was obtained from Sigma Aldrich (St. Louis, MO, USA). Cadmium chloride $\left(\mathrm{CdCl}_{2}\right)$ was purchased from Qualikems Fine Chemicals Ltd. (New Delhi, India). Dimethyl sulfoxide (DMSO) was obtained from Sigma. All other chemicals used were purchased from Merck Chemicals (Germany).

\section{Plant collection and processing}

The whole plant (30 kg of (E. fluctuans)) was collected from fields and canal sides of Maynamati, Cumilla, in the month of November 2016. The National Herbarium Institute (BNHI), Ministry of Environment and Forests Dhaka, Bangladesh identified the plant. The accession number is DACB 46953. The plant materials were sundried and 10 $\mathrm{kg}$ of dried plant was obtained. Then the dried materials were grinded to powder and sieved with 40 mesh size. The two kilograms of fine powder obtained, were used for extraction with 41 of $20 \%$ aqueous alcohol by keeping overnight, the extraction process was repeated thrice (4 $1 \times 3)$. The mixture was filtered by Whatman filter paper (No. 1441090) and a total 9.01 of filtrate was obtained. The filtrate was then evaporated using a vacuum rotary evaporator not exceeding $40^{\circ} \mathrm{C}$. The semi-dried extract was further dried in a freeze drier. The dried material was obtained and stored in an airtight container at $-20^{\circ} \mathrm{C}$ for further analysis.

\section{Experimental animal}

Forty eight adult long evans rats used in the study, 32 were normal and 16 were type 2 diabetic rats weighing 
200-250 g. The animals were bred at Bangladesh University of Health Sciences (BUHS) animal house, Dhaka, Bangladesh. Animals were housed in $20.0 \mathrm{~cm} \times 15.0 \mathrm{~cm} \times$ $7.0 \mathrm{~cm}$ (Length $\mathrm{x}$ Width $\mathrm{x}$ Height respectively) cages. Then allowed to acclimatize for seven days in the environment maintained at a constant room temperature of $22 \pm 5{ }^{\circ} \mathrm{C}$ with humidity of $40-70 \%$ and the natural $12 \mathrm{~h}$ day-night cycle [33]. The animal environment, housing, and management were strictly followed by standard guideline [34]. The rats were fed on a standard laboratory pellet diet and purified water supplied ad libitum. The influence of circadian rhythm was avoided by performing the experiments in the morning. The ethical approval for the study was taken from the Ethical Committee of BUHS, Bangladesh (Reg. no. BUHS/BIO/ $\mathrm{EA} / 18 / 11)$.

\section{Experimental model of diabetes}

Type 2 diabetes was induced by a single intra peritoneal injection of Streptozotocin (STZ) in citrate buffer (10 $\mathrm{mL}$ ) at a dose of $90 \mathrm{mg} / \mathrm{kg}$ body weight (bw) to the rat pups (48 h old, average weight $7 \mathrm{~g}$ ) [35]. The three months old rats were primary assessed following standard guideline of oral glucose tolerance test (OGTT). Streptozotocin induced diabetic model is not the actual type 2 DM model [36]; therefore, our study also included $40 \%$ rats that developed diabetes naturally. The final experimental rats were considered based on fasting blood glucose level $>7.0 \mathrm{mM}$ of $\mathrm{STZ}$ treatment and $>8.0 \mathrm{mM}$ of naturally $\mathrm{DM}$ on day 0 . These rats were distributed equally in both DM-P and DM-PCd groups.

\section{Experimental design}

The animals were divided into the following six groups, four of which were normal and two were diabetic models containing eight $(n=8)$ in each group. The experiment was carried out for 21 days study period.

N-C group: Normal rats with water and dimethyl sulphooxide (DMSO) [10 mg/kg bw].

N-Cd group: Normal rats with Cadmium chloride

$\left(\mathrm{CdCl}_{2}\right)$ treated group [50 mg/kg bw].

N-P group: Normal rats with plant treated (NP) group. Enhydra fluctuans extract (200 mg/kg bw).

N-PCd group: Normal rats with plant (NP) $+\mathrm{CdCl}_{2}$ treated group. $\mathrm{CdCl}_{2}(50 \mathrm{mg} / \mathrm{kg}$ bw $)+$ Enhydra

fluctuans extract $(200 \mathrm{mg} / \mathrm{kg} \mathrm{bw})$.

DM-P group: Diabetic rats with plant treated group. Enhydra fluctuans extract (200 mg/kg bw) was orally administered.

DM-PCd group: Diabetic rats with $\mathrm{CdCl}_{2}+$ plant treated group. $\mathrm{CdCl}_{2}(50 \mathrm{mg} / \mathrm{kg}$ bw $)+$ Enhydra fluctuans extract $(200 \mathrm{mg} / \mathrm{kg} \mathrm{bw})$.
All the treatment regiments were administered orally. Health, food and water intake were monitored daily whilst body weight was determined weekly. After overnight fasting, blood samples $(0.5 \mathrm{~mL})$ were collected from tail-vein using mild ether anesthesia $(5.6 \mathrm{~g} / \mathrm{kg})$ at day 0 and day 21 of treatment period [37]. The fasting blood glucose levels and other biochemical parameters namely total cholesterol (TC), triglycerides (TG), highdensity lipoprotein (HDL), alanine amino transferase (ALT) and creatinine levels were estimated using serum samples.

All the six groups of rats were sacrificed on day 21 after an overnight fast, with anesthetic ether and further by cervical dislocation. After sacrificing, liver and heart samples were immediately collected and stored at $10 \%$ formalin for histological analysis.

\section{Biochemical parameters \\ Estimation of glucose}

Serum glucose was measured by the glucose oxidase (GOD-PAP) method [38], which uses oxidation of glucose to generate gluconic acid and hydrogen peroxide. Hydrogen peroxide $\left(\mathrm{H}_{2} \mathrm{O}_{2}\right)$ forms a red violet color with a chromogenic oxygen acceptor, phenol aminophenazone in the presence of peroxidase (POD). The color intensity is proportional to glucose concentration in the sample.

\section{Estimation of cholesterol}

Serum cholesterol level of the rats was determined after enzymatic hydrolysis and oxidation. The indicator quinoneimine was generated from hydrogen peroxide and 4-aminoantipyrine in the presence of phenol and peroxidase [39].

\section{Estimation of serum triglyceride (TG)}

The serum triglyceride level was estimated by GPO-PAP method using the enzyme glycerol-3-phosphate oxidase by Automated Analyzer [40].

\section{Determination of HDL-cholesterol}

Serum HDL-Cholesterol was determined using the method described previously [39].

\section{Calculation of LDL- cholesterol}

Low density lipoprotein (LDL)-cholesterol was calculated according to the previously described formula [41].

\section{Atherogenic index}

Atherogenic index was calculated using the formula, total TG/HDL-C [42]. 


\section{Estimation of alanine aminotransferase}

It is an adaptation of alanine aminotransferase procedure of the IFCC as described previously [43]. This procedure is modified by adding of pyridoxal-5-phosphate (P5P) as an activator to replace phosphate buffer with tris (hydroxymethyl) aminomethane.

\section{Estimation of creatinine}

The serum creatinine level was measured using a modification of kinetic Jaffe reaction [44].

All serum biochemical parameters were estimated by enzymatic colorimetric method using Dimension ${ }^{\circ}$ clinical chemistry system, SIMENS, Germany.

\section{Histological analysis}

For histological studies, liver and heart portions were excised and fixed in $10 \%$ formalin for $24 \mathrm{~h}$. After fixing the tissue, it was dehydrated by a graded series of ethyl alcohol (70 to 100\%) and cleared by toluene, then embedded in paraffin wax. Sections of paraffin blocks were cut by a rotary microtome $(5 \mu \mathrm{m})$ Leica 2235 scanner (Germany) and stained with haematoxylin and eosin (H\&E) [45]. The samples were examined under a light microscope (Zeiss Axio Scope.A1, Germany) and images were taken at 20X and 40X magnification.

\section{Statistical analysis}

Statistical analysis was performed by Statistical Package for Social Sciences (software for windows version 16 (SPSS Inc., Chicago, Illinois, USA). Data were expressed as mean \pm standard deviation or median (range). Comparison within groups was performed using paired t-test while one-way ANOVA followed by Dunnett's test were used between groups. To estimate the correlation between dependent and independent variables, Pearson's correlation was perfomed, a $p<0.05$ was considered statistically significant.

\section{Results}

\section{Glycemic status of the study subjects}

In the six rat models, fasting serum glucose (FSG) levels were comparable within normal models and diabetic models on day 0 . After oral administration of respective treatments for 21 days, the corresponding FSG level was significantly reduced in N-PCd, DM-PCd and DM-P groups [mean $\pm \mathrm{SD}, \mathrm{mmol} / \mathrm{l} ;(6.71 \pm 0.97,8.22 \pm 0.83$ and $7.80 \pm 0.44)$ day 0 vs $(6.24 \pm 0.92,6.74 \pm 1.45$ and $6.70 \pm$ 0.44 ) day 21 respectively; $\mathrm{p}<0.05$ and $p<0.01$ ] (Table 1 ). So, E. fluctuans plant retained potent glucose lowering effects both in hyperglycemia and in Cd toxicity. The comparative analyses among the different groups at baseline and endpoint of the study were also performed. The baseline glucose was significantly different among the study groups confirmed by $\mathrm{F}$ test $(\mathrm{F}=7.841, p<$ 0.001 ), however, the significance level disappeared at endpoint of the treatment (Table 2).

\section{Effects of $E$. fluctuans on serum cholesterol, triglyceride, HDL-cholesterol and atherogenic index}

In the lipidemic status, none of the six groups showed significant difference regarding serum total cholesterol, TG and HDL-C between day 0 and day 21 (Table 3). However, the atherogenic index calculated from the ratio of TG to HDL-C showed significant difference from the day 21 to baseline index. Ethanolic extracts significantly decreased serum TG to HDL-C ratio in N-P and DMPCd groups $(p<0.05)$.

\section{Effects of $E$. fluctuans extracts and cadmium on body weight, liver and kidney}

As for body weight measurement, all cadmium treated groups (N-Cd, N-PCd and DM-PCd) showed a significant reduction in body weight on day $21(p<0.01)$. In contrast, no significant changes in body weight were observed in non-Cd-treated (N-C, N-P and DM-P) groups $(\mathrm{p}=\mathrm{ns})$. To compare the deleterious effects of $\mathrm{Cd}$ and plant on liver and kidney, serum GPT and creatinine levels among the six groups on day 0 and day 21 were depicted in Table 4. Liver function was significantly impaired in N-PCd $(p<0.001)$ and Cd treated groups $\mathrm{N}$ Cd ( $<0.05)$, but kidney impairment was only observed in $\mathrm{N}-\mathrm{Cd}(\mathrm{p}<0.05)$ group (Table 4$).$

\section{Correlation}

Several significant correlations were observed when different groups were analyzed. One of the most important correlation was the association of FSG with serum GPT on day 21 in DM-P $(r=0.920, p=0.009)$ and the merged

Table 1 Effects of E. fluctuans extract on glycemic levels in the study groups

\begin{tabular}{lllllll}
\hline Parameter & $\begin{array}{l}\mathrm{N}-\mathrm{C} \\
(n=8)\end{array}$ & $\begin{array}{l}\mathrm{N}-\mathrm{Cd} \\
(n=7)\end{array}$ & $\begin{array}{l}\mathrm{N}-\mathrm{P} \\
(n=7)\end{array}$ & $\begin{array}{l}\mathrm{N}-\mathrm{PCd} \\
(n=7)\end{array}$ & $\begin{array}{l}\text { DM-P } \\
(n=6)\end{array}$ & $\begin{array}{l}\text { DMP-Cd } \\
(n=5)\end{array}$ \\
\hline Fasting Serum Glucose $(\mathrm{mM})$ & & & & & \\
Day 0 & $5.59 \pm 0.87$ & $6.75 \pm 1.19$ & $6.37 \pm 0.69$ & $6.71 \pm 0.97$ & $7.80 \pm 0.44$ & $8.22 \pm 0.83$ \\
Day 21 & $6.04 \pm 0.91$ & $6.75 \pm 0.74$ & $6.31 \pm 1.18$ & $6.24 \pm 0.92^{*}$ & $6.70 \pm 0.41^{* *}$ & $6.74 \pm 1.45^{*}$ \\
\hline
\end{tabular}

Results are expressed as Mean \pm SD. Statistical analysis within groups was done using paired t-test. SD Standard deviation, $N$ - C Normal Control, $N$ - $C d$ Normal treated with $\mathrm{CdCl}_{2}, \mathrm{~N}-\mathrm{P}$ Normal treated with plant extract; $\mathrm{N}-\mathrm{PCd}$ Normal treated with both plant extract and $C \mathrm{CCl} \mathrm{L}_{2}, D M-P$ Diabetic treated with plant extract, $D M-$ $P C d$ Diabetic treated with both plant extract and $\mathrm{CdCl}_{2} .{ }^{*},{ }^{* *}$ and ${ }^{* * *}$ indicate statistically significant $(p<0.05, p<0.01$ and $<0.001)$ level from a paired t-test 
Table 2 Comparison of glycemic status before and after E. fluctuans treatments

\begin{tabular}{|c|c|c|c|c|c|c|c|}
\hline \multirow[t]{2}{*}{ Group } & \multicolumn{4}{|c|}{ Before Treatment } & \multicolumn{3}{|c|}{ After Treatment } \\
\hline & $\begin{array}{l}\text { FSG }(m M) \\
\text { Mean } \pm \text { SD }\end{array}$ & Mean difference \pm SE & $\begin{array}{l}\text { F ratio } \\
\text { (Significance) }\end{array}$ & $p$ value & $\begin{array}{l}\text { FSG }(m M) \\
\text { Mean } \pm \text { SD }\end{array}$ & Mean difference \pm SE & $\begin{array}{l}\text { F ratio } \\
\text { (Significance) }\end{array}$ \\
\hline $\mathrm{N}-\mathrm{C}$ & $5.59 \pm 0.87$ & & \multirow{6}{*}{$\begin{array}{c}7.841 \\
(p<0.001)\end{array}$} & & $6.04 \pm 0.91$ & & \multirow{6}{*}{$\begin{array}{c}0.647 \\
(p=0.666)\end{array}$} \\
\hline $\mathrm{N}-\mathrm{Cd}$ & $6.75 \pm 1.19$ & $1.16 \pm 0.47$ & & 0.072 & $6.75 \pm 0.74$ & $0.71 \pm 0.53$ & \\
\hline$N-P$ & $6.37 \pm 0.69$ & $0.79 \pm 0.43$ & & 0.270 & $6.31 \pm 1.18$ & $0.28 \pm 0.49$ & \\
\hline $\mathrm{N}-\mathrm{PCd}$ & $6.71 \pm 0.98$ & $1.13 \pm 0.45$ & & 0.067 & $6.24 \pm 0.92$ & $0.21 \pm 0.51$ & \\
\hline DM-P & $7.80 \pm 0.44$ & $2.20 \pm 0.47$ & & $<0.001^{* * *}$ & $6.70 \pm 0.41$ & $0.66 \pm 0.53$ & \\
\hline DMP-Cd & $8.22 \pm 0.83$ & $2.63 \pm 0.49$ & & $<0.001^{* * *}$ & $6.74 \pm 1.45$ & $0.70 \pm 0.56$ & \\
\hline
\end{tabular}

Results are expressed as Mean \pm SD and Mean difference \pm SE. Mean differences were calculated in comparison to Control group (N-C). SD Standard deviation, SE Standard error of mean, FSG Fasting serum glucose. ${ }^{* * *}$ indicates statistically significant $(p<0.001)$ level from one-way ANOVA and Dunnett's test

group $(\mathrm{r}=0.313, p=0.043)$ (Table 5). This association was also found $(p=0.05)$ in N-PCd at baseline that disappeared after 21 days of treatment period. No significant correlation was observed from the remaining groups either on day 0 or day $21(\mathrm{p}=\mathrm{ns})$. The correlation between SGPT and TG/HDL-C on day 21 was found to be significantly associated with the merged group $(p<0.01)$, NP and DMP $(<0.05)$ (Table 5).

\section{Effects of $E$. fluctuans extract on liver and heart histology}

The liver and heart histopathological investigations were showed in Figs. 1 and 2. Compared to the control group (Fig. 1 a) there were severe inflammatory cells, hydropic degeneration, vacuolation of liver cell, nuclear pyknosis, karyorrhexis, fatty changes, and fibrosis were found in the $\mathrm{Cd}$ treated groups (Fig. $1 \mathrm{~b}$ and d). No major abnormalities were found in the plant extract treated group (Fig. 1 c). Similarly, the protective effects of the plant were observed in the DM-P group (Fig. 1e), which exhibited mild nuclear pyknosis, less inflammation and fibrosis compared to the DM-PCd group (Fig. 1 f). The histopathology of arch of aorta showed normal architecture in control rats (Fig. 2 a). Various abnormalities including loss of myocardial fibers, hyalinization, vacuolization of cytoplasm, nuclear pyknosis, necrosis, and fatty changes were clearly demonstrated in the N-Cd and N-PCd groups (Fig. $2 \mathrm{~b}$ and d). On the other hand, normal myocytes with mild inflammation and low fat deposition were observed in the plant extract treated group (Fig. 2 c). There are no major abnormalities were found in the DM-P group (Fig. 2 e) compared to the DMP-Cd which demonstrated inflammatory cells, vacuolization of cytoplasm, myocardial fibers loss, steatosis and less necrosis (Fig. $2 \mathrm{f}$ ). Thus, the plant extracts might confer some sort of protective activities against cadmium-induced toxicity.

\section{Discussion}

Type 2 diabetes is a heterogeneous disease that imposes a heavy burden on global health through microvascular and macrovascular complications [3, 4]. The metabolic outcomes of this disease deteriorate in the presence of cadmium $[14,20]$. In this study, we initially identified antidiabetic and antidyslipidemic effects of Enhydra fluctuans extracts in normal and type 2 model rats. We further explored antidiabetic efficacy of the plant in $\mathrm{Cd}$ toxicity.

The present study revealed that the ethanolic extracts of E. fluctuans at a dose of $200 \mathrm{mg} / \mathrm{kg}$ significantly reduced fasting blood glucose level $(p<0.05)$ in normal (N-PCd) and diabetic (DM-P, DM-PCd) rat models (Table 1) and it was more pronounced in mergeddiabetic group $(p<0.001)$ (data were not shown). The

Table 3 Effects of E. fluctuans on lipid profile and atherogenic index in the study subjects

\begin{tabular}{|c|c|c|c|c|c|c|c|}
\hline Para-meters & Days & $\mathrm{N}-\mathrm{C}$ & $\mathrm{N}-\mathrm{Cd}$ & $\mathrm{N}-\mathrm{P}$ & $\mathrm{N}-\mathrm{PCd}$ & DM-P & DMP-Cd \\
\hline \multirow[t]{2}{*}{ Chol (mg/dl) } & 0 day & $75 \pm 19$ & $72 \pm 18$ & $76 \pm 18$ & $73 \pm 15$ & $75 \pm 15$ & $75 \pm 10$ \\
\hline & 21 day & $67 \pm 8$ & $75 \pm 8$ & $68 \pm 7$ & $68 \pm 15$ & $84 \pm 12$ & $73 \pm 13$ \\
\hline \multirow[t]{2}{*}{ TG (mg/dl) } & 0 day & $58 \pm 18$ & $57 \pm 15$ & $55 \pm 13$ & $62 \pm 21$ & $53 \pm 5$ & $83 \pm 12$ \\
\hline & 21 day & $51 \pm 8$ & $50 \pm 12$ & $48 \pm 18$ & $61 \pm 18$ & $56 \pm 10$ & $56 \pm 12$ \\
\hline \multirow[t]{2}{*}{$\mathrm{HDL}-\mathrm{C}(\mathrm{mg} / \mathrm{dl})$} & 0 day & $65 \pm 15$ & $64 \pm 16$ & $59 \pm 9$ & $65 \pm 17$ & $67 \pm 14$ & $58 \pm 4$ \\
\hline & 21 day & $65 \pm 11$ & $70 \pm 7$ & $64 \pm 7$ & $63 \pm 15$ & $78 \pm 10$ & $68 \pm 13$ \\
\hline \multirow[t]{2}{*}{ TG/HDL-C ratio } & 0 day & $0.75(0.49-2.38)$ & $0.84(0.62-1.41)$ & $0.89(0.74-1.24)$ & $0.90(0.59-1.92)$ & $0.83(0.66-0.98)$ & $1.57(1.07-1.64)$ \\
\hline & 21 day & $0.74(0.60-1.15)$ & $0.65(0.60-1.12)$ & $0.66(0.48-1.27)^{*}$ & $0.82(0.62-1.89)$ & $0.74(0.47-0.96)$ & $0.81(0.63-1.08)^{*}$ \\
\hline
\end{tabular}

Results are expressed as Mean \pm SD or Median (range) as appropriate. Statistical analysis within groups was done using paired t-test and WilCoxon rank sum test. SD, Standard deviation; ${ }^{*}$ and ${ }^{* *}$ indicate statistically significant $(p<0.05$ and $p<0.01)$ levels from a paired t-test 
Table 4 Effects of E. fluctuans and cadmium on body weight, liver and kidney function

\begin{tabular}{llllllll}
\hline Parameters & Days & $\mathrm{N}-\mathrm{C}$ & $\mathrm{N}-\mathrm{Cd}$ & $\mathrm{N}-\mathrm{P}$ & $\mathrm{N}-\mathrm{PCd}$ & $\mathrm{DM}-\mathrm{P}$ & $\mathrm{DM}-\mathrm{PCd}$ \\
\hline Weight $(\mathrm{g})$ & 0 day & $225 \pm 14$ & $223 \pm 10$ & $226 \pm 13$ & $234 \pm 14$ & $231 \pm 13$ & $220 \pm 16$ \\
& 21 day & $217 \pm 16$ & $203 \pm 10^{* *}$ & $221 \pm 19$ & $201 \pm 25^{* *}$ & $221 \pm 10$ & $187 \pm 24^{* *}$ \\
SGPT $(\mathrm{mg} / \mathrm{dl})$ & 0 day & $58 \pm 19$ & $59 \pm 8$ & $53 \pm 10$ & $73 \pm 29$ & $72 \pm 40$ & $62 \pm 13$ \\
& 21 day & $75 \pm 15$ & $106 \pm 39^{*}$ & $69 \pm 21$ & $123 \pm 37^{* * *}$ & $87 \pm 33$ & $68 \pm 13$ \\
Creatinine $(\mathrm{mg} / \mathrm{dl})$ & 0 day & $0.51 \pm 0.06$ & $0.48 \pm 0.10$ & $0.51 \pm 0.06$ & $0.56 \pm 0.05$ & $0.57 \pm 0.08$ & $0.56 \pm 0.15$ \\
& 21 day & $0.59 \pm 0.08$ & $0.60 \pm 0.09^{*}$ & $0.58 \pm 0.07$ & $0.63 \pm 0.07$ & $0.52 \pm 0.04$ & $0.46 \pm 0.05$
\end{tabular}

Results are expressed as Mean \pm SD. Statistical analysis within groups was done using paired t-test. SD, Standard deviation; ${ }^{*}{ }^{* *}$ and ${ }^{* * *}$ indicate statistically significant $(p<0.05, p<0.01$ and $p<0.001)$ levels from a paired t-test

antidiabetic effects were further confirmed by comparing within and between the study groups (Table 2). In both ways, the plant showed significant antihyperglycemic activity and it was preserved even under $\mathrm{Cd}$ induced condition. Our results are in agreement with reported literature from traditional medicine practitioners that $E$. fluctuans exhibits antidiabetic activity [32, 46]. This effect is attributed to the various agents present in the plant that may enhance glucose uptake and prevent hyperglycemia through several mechanisms such as increased inhibitory effects against insulinase, reduced hepatic inflammation and improved insulin sensitivity $[28,31,47]$. As well as other mechanisms also involved such as inhibition of intestinal glucose absorption, enhanced peripheral glucose utilization, hepatic glycogen synthesis or decrease of glycogenolysis [30, 31, 47, 48]. In contrast, $\mathrm{CdCl}_{2}$ alone had no effect on glucose metabolism. This study is in consistent with the findings of reported literature that short time exposure of $\mathrm{Cd}$ seems to have no direct effects on glucose metabolism. Its effects may come from chronic exposure by pancreatic impairment and insulin resistance in multiple peripheral tissues [16]. Our study found direct effects on body weight reduction, liver and kidney impairment, which

Table 5 The association of fasting serum glucose, SGPT and TG/ $\mathrm{HDL}$ ratio in the study groups

\begin{tabular}{|c|c|c|c|c|}
\hline \multirow[t]{2}{*}{ Groups } & \multicolumn{2}{|c|}{ FSG vs SGPT } & \multicolumn{2}{|c|}{ SGPT vs TG/HDL ratio } \\
\hline & Day 0 (r) & Day $21(r)$ & Day 0 (r) & Day $21(r)$ \\
\hline Merged group & +0.121 & $+0.313^{\mathrm{a}}$ & +0.056 & $+0.410^{b}$ \\
\hline $\mathrm{N}-\mathrm{C}$ & -0.459 & +0.569 & -0.100 & -0.291 \\
\hline $\mathrm{N}-\mathrm{Cd}$ & +0.188 & +0.728 & -0.113 & -0.675 \\
\hline $\mathrm{N}-\mathrm{P}$ & -0.464 & +0.351 & +0.498 & $+0.836^{a}$ \\
\hline $\mathrm{N}-\mathrm{PCd}$ & $+0.755^{\mathrm{a}}$ & +0.404 & +0.277 & +0.681 \\
\hline DM-P & -0.592 & $+0.920^{\mathrm{b}}$ & +0.314 & $+0.882^{\mathrm{a}}$ \\
\hline DM-PCd & -0.188 & -0.179 & +0.122 & -0.339 \\
\hline
\end{tabular}

$\mathrm{r}$, Correlation coefficient; ${ }^{\mathrm{a}}$ and ${ }^{\mathrm{b}}$ indicate significance at 0.05 and 0.01 levels (2-tailed) may be due to the higher dose of $\mathrm{CdCl} 2$ induction for consecutive 21 days. Previous studies have also shown that $\mathrm{Cd}$ treatment reduced body weight gain and increased liver dysfunction in a dose dependent manner $[13,49]$. Impaired hepatic function induced by Cd prevents lowering of blood glucose and TG/HDL-C ratio leading to worsened metabolic regulation $[16,18]$. This was clearly demonstrated from the association of serum glucose, GPT and TG/HDL-C ratio in N-PCd, N-P, DM-P and the merged group (Table 5). It was also evident from histological diagnosis of hepatocytes that show severe inflammatory cells, hydropic degeneration, vacuolation, nuclear pyknosis, karyorrhexis, and fibrosis in the $\mathrm{Cd}$ treated groups (Fig. 1). One possible mechanism of hepatotoxicity is the oxidation state in which $\mathrm{Cd}$ can replace zinc present in metallothionein, thereby inhibiting it from acting as a free radical scavenger within the cell [50]. The histology of the arch of the aorta showed that plant treatment protects from vascular degradation, vacuolization of cytoplasm, hyalinization, necrosis and fibrosis (Fig. 2). This similar protective effects of Tinospora cordifolia (TCME) on $\mathrm{Cd}$-induced cardiotoxicity prevented the alteration of serum marker enzymes (creatine kinase and lactate dehydrogenase), antioxidants, and glycoproteins contents [51]. Therefore, E fluctuans may have potent agents that could directly ameliorate glucose metabolism and partially neutralize toxicities generated by Cadmium.

The plant extract did not show any direct effect on total blood lipids in the study. However, most of the plant treated groups showed a reduced ratio of TG/ HDL-C (Table 3), indicating the potential improvement of insulin sensitivity in diabetes. While the increased TG/HDL-C represented central obesity, which is directly associated with insulin resistant by altering secretion of different adipocytokines namely adiponectin, leptin, resistin and visfatin [52]. In addition to insulin resistance, TG/HDL-C ratio could predict accurately the risk for CHD and CVD mortality [52, 53]. These results are in good correlation with earlier reports, which stated that high triglycerides with low HDL-C leads to diabetes 


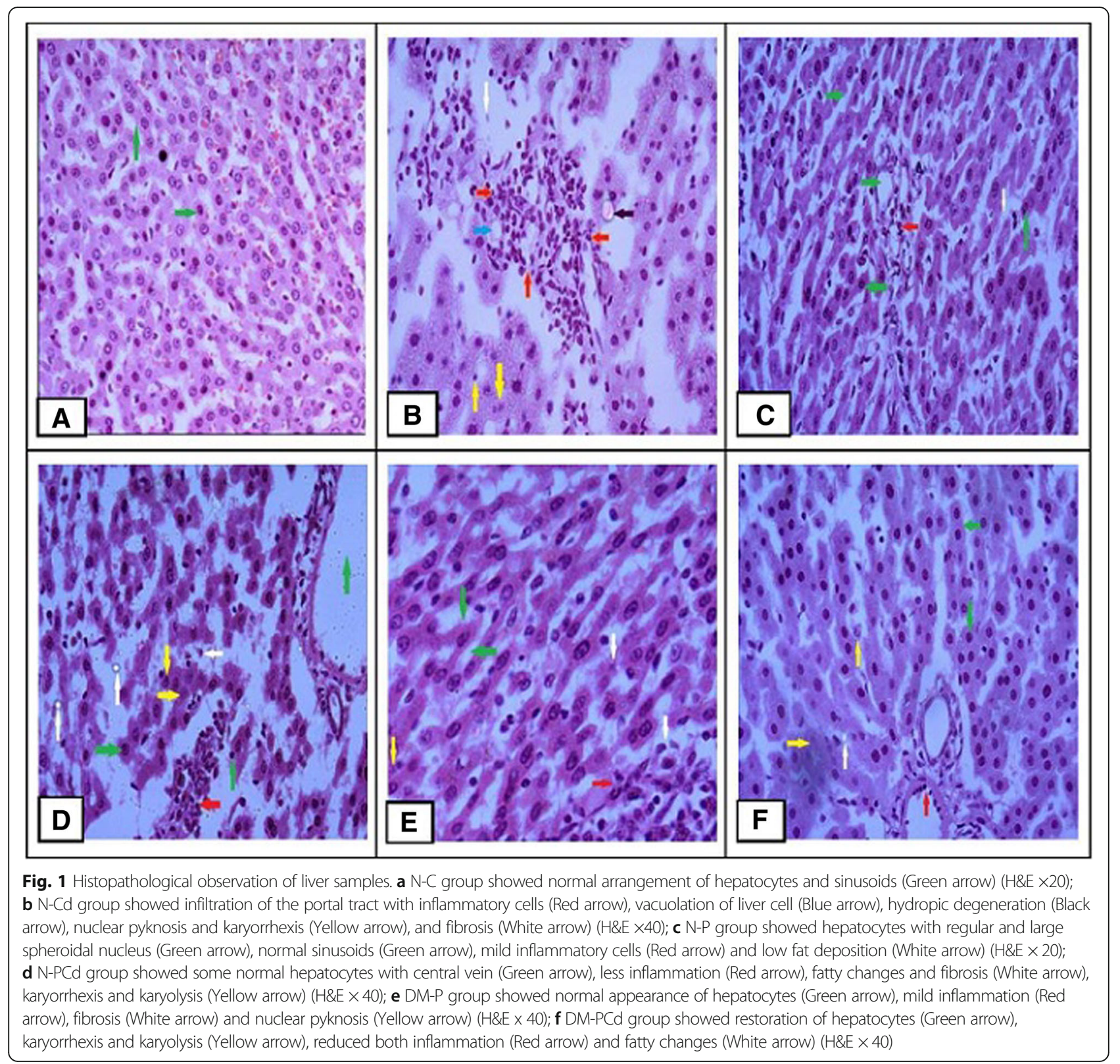

onset [54]. However, our study was unable to inhibit individual lipid parameters [55] and failed to reduce TG/ HDL-C ratio in DM-P group. Despite these limitations, our plant improved TG/HDL-C ratio even in subjects with normal lipid profile. Hence, the plant could ameliorate metabolic regulation at the early stage of the development of metabolic disorders.

Although cadmium concentration was not measured in the plant extract, it has not shown any adverse effects on body weight loss, liver and kidney impairment both in normal and diabetic models. The presence of ascorbic acid, phenolics and flavonoids in
Enhydra fluctuans extracts stimulates redox parameters and inhibits lipid peroxidation, protein carbonylation, intrinsic and extrinsic apoptotic markers which were responsible for overall protective effect $[47,48]$. Lack of diabetic controls and standard drug group was a limitation in our study.

\section{Conclusion}

We present a plant with potential antihyperglycemic and partial antihyperlipidemic activities in both diabetes and $\mathrm{Cd}$ toxicity conditions. This plant is able to ameliorate the synergistic action of $\mathrm{Cd}$ and diabetes 


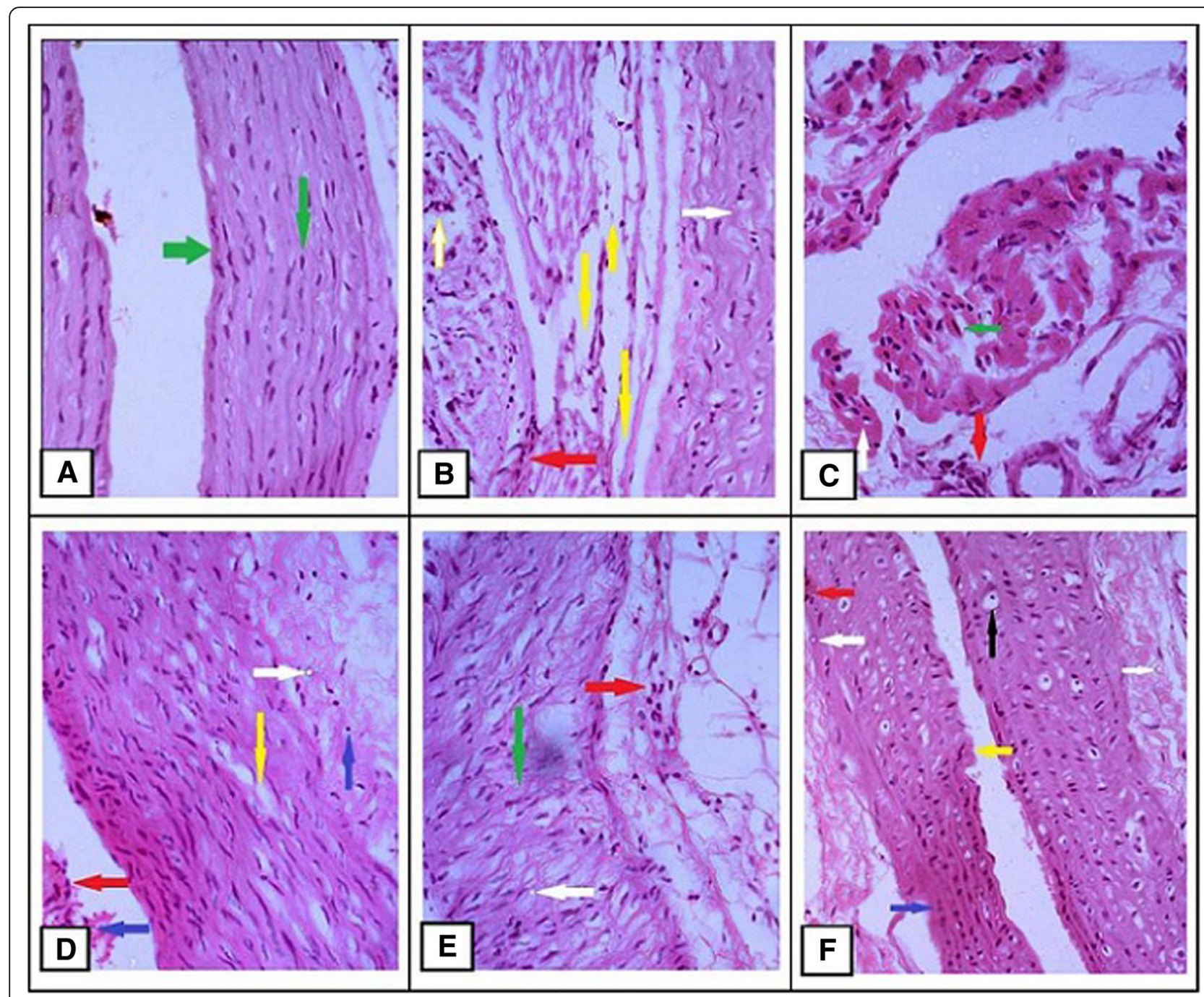

Fig. 2 Histopathological observation of heart samples. Histopathological observation of heart in the study groups a N-C group showed normal myocardial fibers with membrane integrity (Green arrow) (H\&E $\times 20)$; b N-Cd group showed inflammation (Red arrow), severe loss of myocardial fibers and hyalinization (Yellow arrow), and fatty changes (White arrow) (H\&E $\times 20)$; c N-P group showed normal myocytes (Green arrow), mild inflammation (Red arrow) and low fat deposition (White arrow) (H\&E $\times 40$ ); d N-PCd group showed inflammation (Red arrow), less irregularity of myofibrils (Yellow arrow), fat deposition (White arrow), nuclear pyknosis and necrosis (Blue arrow) (H\&E $\times 20)$; e DM-P group showed mild inflammation (Red arrow) including fatty changes (White arrow), and normal myocardial fibers (Green arrow) (H\&E $\times 20)$; $\mathbf{f}$ DM-PCd group showed less inflammatory cells (Red arrow), vacuolization of cytoplasm (Black arrow), myocardial fibers loss (Yellow arrow), steatosis (White arrow) and less necrosis (Blue arrow) $(H \& E \times 20)$

using various phyto-chemical compounds possess in the plant. Our findings provided scientific confirmation for the safe use of E. fluctuans by traditional healers in the treatment of diabetes. This study would enable additional efforts to move E. fluctuans closer to clinical relevance.

\section{Abbreviations}

ALT: Alanine amino transferase; Bw: Body weight; $\mathrm{CdCl}_{2}$ : Cadmium; Chol: Cholesterol; DM: Diabetic Mellitus; DM-P : Diabetic Mellitus Plant treated; DM-PCd: Diabetic Mellitus Plant + Cadmium $\left(\mathrm{CdCl}_{2}\right)$ treated; DMSO: Dimethyl sulfoxide; FSG: Fasting Serum Glucose; H\&E: Haematoxylin and Eosin; HDL: High-Density Lipoprotein; N-C: Normal water control; $\mathrm{N}-\mathrm{Cd}$ : Normal Cadmium $\left(\mathrm{CdCl}_{2}\right)$; N-P: Normal plant treated; N-PCd: Normal plant + Cadmium $\left(\mathrm{CdCl}_{2}\right)$ treated; SGPT: Serum Glutamic Pyruvic Transaminase; STZ: Streptozotocin; TC: Total Cholesterol; TG: Triglycerides

\section{Acknowledgments}

We are grateful to professor Liaquat Ali for giving permission to accomplish the study in Bangladesh University of Health Sciences (BUHS). We are also gratefully acknowledged to the Ministry of Science and Technology (MOST), Bangladesh, for funding the project.

\section{Authors' contributions}

MNH and FS performed experimental and laboratory analysis, and drafting the manuscript. BR prepared the experimental rat models. MSHK carried out the extraction of the Enhydra fluctuans. MUA performed the histopathological analysis. AM improved the quality and proofread the manuscript. MMB designed the study and editing of the manuscript. SA 
designed the study, data analysis, editing the manuscript and funding of the project. All authors have read and approved the manuscript.

\section{Funding}

The Ministry of Science and Technology (MOST), Bangladesh (Grant no.39.00.0000.09.02.69.16-17/BS-184/198) funded the study. Asian Network on Research on Antidiabetic Plants (ANRAP) partially supported the study.

\section{Availability of data and materials}

The author has the availability of data and material in the selected repository.

\section{Ethics approval and consent to participate}

The study has been taken ethical approval from the Ethical Committee of BUHS, Bangladesh. The registration no is BUHS/BIO/EA/18/11.

\section{Consent for publication}

Not applicable.

\section{Competing interests}

The authors declare that they have no competing interests.

\section{Author details}

'Department of Biotechnology and Genetic Engineering, Mawlana Bhashani Science and Technology University, Santosh, Tangail 1902, Bangladesh. ${ }^{2}$ Department of Pharmacology, Bangladesh University of Health Sciences, Dhaka 1216, Bangladesh. ${ }^{3}$ Department of Chemistry, Bangladesh University of Health Sciences, Dhaka 1216, Bangladesh. ${ }^{4}$ Department of Pathology, Bangladesh University of Health Sciences, Dhaka 1216, Bangladesh. ${ }^{5}$ Department of Health and Social Care, St. Patrick's College, London, UK. ${ }^{6}$ Biotechnology and Genetic Engineering Discipline, Khulna University, Khulna 9208, Bangladesh. ${ }^{2}$ Department of Medical Biotechnology, Bangladesh University of Health Sciences, Dhaka 1216, Bangladesh.

\section{Received: 22 February 2019 Accepted: 30 August 2019}

Published online: 22 October 2019

\section{References}

1. Association AD. Diagnosis and classification of diabetes mellitus. Diabetes Care. 2014;37(Supplement 1):S81-90.

2. Key facts of Diabetes [https://www.who.int/news-room/fact-sheets/ detail/diabetes]. Accessed 30 Oct 2018.

3. Alaboud AF, Tourkmani AM, Alharbi TJ, Alobikan AH, Abdelhay O, Al Batal $\mathrm{SM}$, et al. Microvascular and macrovascular complications of type 2 diabetic mellitus in central, Kingdom of Saudi Arabia. Saudi Med J. 2016;37(12):1408.

4. Kosiborod M, Gomes MB, Nicolucci A, Pocock S, Rathmann W, Shestakova MV, Watada H, Shimomura I, Chen H, Cid-Ruzafa J et al. Vascular complications in patients with type 2 diabetes: prevalence and associated factors in 38 countries (the DISCOVER study program). Cardiovasc Diabetol. 2018:17(1):150.

5. Diabetes Prevention Program Research G, Hamman RF, Horton E, Barrett Connor E, Bray GA, Christophi CA, et al. Factors affecting the decline in incidence of diabetes in the diabetes prevention program outcomes study (DPPOS). Diabetes. 2015;64(3):989-98.

6. Edwards J, Ackerman C. A review of diabetes mellitus and exposure to the environmental toxicant cadmium with an emphasis on likely mechanisms of action. Curr Diabetes Rev. 2016:12(3):252-8.

7. Chen YW, Yang CY, Huang CF, Hung DZ, Leung YM, Liu SH. Heavy metals, islet function and diabetes development. Islets. 2009;1(3):169-76.

8. Wuana RA, Okieimen FE. Heavy Metals in Contaminated Soils: A Review of Sources, Chemistry, Risks and Best Available Strategies for Remediation. ISRN Ecology 2011:2011:1-20.

9. Rocco C, Seshadri B, Adamo P, Bolan NS, Mbene K, Naidu R. Impact of waste-derived organic and inorganic amendments on the mobility and bioavailability of arsenic and cadmium in alkaline and acid soils. Environ Sci Pollut Res Int. 2018;25(26):25896-905.

10. Rehman K, Fatima F, Waheed I, Akash MSH. Prevalence of exposure of heavy metals and their impact on health consequences. J Cell Biochem. 2018;119(1):157-84.
11. Luevano J, Damodaran C. A review of molecular events of cadmiuminduced carcinogenesis. J Environ Pathol Toxicol Oncol. 2014;33(3):183-94.

12. Peng L, Huang Y-T, Zhang F, Chen J-Y, Huo X. Chronic cadmium exposure aggravates malignant phenotypes of nasopharyngeal carcinoma by activating the Wnt/ $\beta$-catenin signaling pathway via hypermethylation of the casein kinase 1a promoter. Cancer Manag Res. 2019;11:81.

13. Kamenova K, Gluhcheva Y, Vladov I, Stoykova S, Ivanova J. Ameliorative effect of the anticancer agent salinomycin on cadmium-induced hepatotoxicity and renal dysfunction in mice. Environ Sci Pollut Res Int. 2018;25(4):3616-27.

14. Tinkov AA, Filippini T, Ajsuvakova OP, Aaseth J, Gluhcheva YG, Ivanova JM, et al. The role of cadmium in obesity and diabetes. Sci Total Environ. 2017:601:741-55.

15. Pizzino GIN, Bitto A, Pallio G, Mannino F, Arcoraci V, Aliquò F, et al. Cadmium-induced oxidative stress impairs glycemic control in adolescents. Oxidative Med Cell Longev. 2017;2017:6.

16. Trevino S, Waalkes MP, Flores Hernandez JA, Leon-Chavez BA, AguilarAlonso P, Brambila E. Chronic cadmium exposure in rats produces pancreatic impairment and insulin resistance in multiple peripheral tissues. Arch Biochem Biophys. 2015;583:27-35.

17. Valcke M, Ouellet N, Dube M, Laouan Sidi EA, LeBlanc A, Normandin L, et al. Biomarkers of cadmium, lead and mercury exposure in relation with early biomarkers of renal dysfunction and diabetes: results from a pilot study among aging Canadians. Toxicol Lett. 2019;312:148-56.

18. Wu C, Zhang Y, Chai L, Wang H. Histological changes, lipid metabolism and oxidative stress in the liver of Bufo gargarizans exposed to cadmium concentrations. Chemosphere. 2017;179:337-46.

19. Orr SE, Bridges CC. Chronic kidney disease and exposure to nephrotoxic metals. Int J Mol Sci. 2017;18(5):1039.

20. Edwards JR, Prozialeck WC. Cadmium, diabetes and chronic kidney disease. Toxicol Appl Pharmacol. 2009;238(3):289-93.

21. Chan CW, Yu CL, Lin JC, Hsieh YC, Lin CC, Hung CY, et al. Glitazones and alpha-glucosidase inhibitors as the second-line oral anti-diabetic agents added to metformin reduce cardiovascular risk in type 2 diabetes patients: a nationwide cohort observational study. Cardiovasc Diabetol. 2018;17(1):20.

22. Wu JH, Foote C, Blomster J, Toyama T, Perkovic V, Sundstrom J, et al. Effects of sodium-glucose cotransporter-2 inhibitors on cardiovascular events, death, and major safety outcomes in adults with type 2 diabetes: a systematic review and meta-analysis. Lancet Diabetes Endocrinol. 2016;4(5):411-9.

23. Alam F, Islam MA, Mohamed M, Ahmad I, Kamal MA, Donnelly R, et al. Efficacy and safety of pioglitazone monotherapy in type 2 diabetes mellitus: a systematic review and meta-analysis of randomised controlled trials. Sci Rep. 2019;9(1):5389.

24. He JH, Chen LX, Li H. Progress in the discovery of naturally occurring antidiabetic drugs and in the identification of their molecular targets. Fitoterapia. 2019;134:270-89.

25. Potunuru UR, Priya KV, Varsha M, Mehta N, Chandel S, Manoj N, et al. Amarogentin, a secoiridoid glycoside, activates AMP- activated protein kinase (AMPK) to exert beneficial vasculo-metabolic effects. Biochim Biophys Acta, Gen Subj. 2019;1863(8):1270-82.

26. $\mathrm{Xu} \mathrm{L,} \mathrm{Li} \mathrm{Y,} \mathrm{Dai} \mathrm{Y,} \mathrm{Peng} \mathrm{J.} \mathrm{Natural} \mathrm{products} \mathrm{for} \mathrm{the} \mathrm{treatment} \mathrm{of} \mathrm{type} 2$ diabetes mellitus: pharmacology and mechanisms. Pharmacol Res. 2018;130:451-65.

27. Sannigrahi S, Mazumder UK, Mondal A, Pal D, Mishra SL, Roy S. Flavonoids of Enhydra fluctuans exhibit anticancer activity against Ehrlich's ascites carcinoma in mice. Nat Prod Commun. 2010;5(8):1239-42.

28. Swain PK, Dinda SC, Nayak DP, kar B, Patro VJ. Antioxidant activity of Enhydra fluctuans Lour. Aerial parts. J Phytother Pharmacol. 2012;1(2):23-34.

29. Lone MI, He Z-L, Stoffella PJ, Yang X-E. Phytoremediation of heavy metal polluted soils and water: progresses and perspectives. J Zhejiang Univ Sci B. 2008;9(3):210-20.

30. Swain PK, Patro VJ, Dinda SC, Nayak DP. Hepatoprotective Activity of Enhydra Fluctuans Lour. Aerial Parts against Ccl4 Induced Hepatotoxicity in Rats. Int J Res Ayurveda and Pharmacy. 2012;3(6):893-6.

31. Kuri S, Billah MM, Rana SM, Naim Z, Islam MM, Hasanuzzaman M, et al. Phytochemical and in vitro biological investigations of methanolic extracts of Enhydra fluctuans Lour. Asian Pac J Trop Biomed. 2014;4(4):299-305

32. Rahmatullah M, Azam MN, Khatun Z, Seraj S, Islam F, Rahman MA, et al. Medicinal plants used for treatment of diabetes by the Marakh sect of the Garo tribe living in Mymensingh district, Bangladesh. Afr J Tradit Complement Altern Med. 2012;9(3):380-5. 
33. Science USOo, Technology P. Laboratory animal welfare; U.S. government principles for the utilization and care of vertebrate animals used in testing, research and training; notice. Fed Regist. 1985;50(97):20864-5.

34. Council NR. Guide for the care and use of laboratory animals: eighth edition. Washington, DC: The National Academies Press; 2011.

35. Bonner-Weir S, Trent D, Honey R, Weir G. Responses of neonatal rat islets to streptozotocin: limited B-cell regeneration and hyperglycemia. Diabetes. 1981:30(1):64-9.

36. Zhuo J, Zeng Q, Cai D, Zeng X, Chen Y, Gan H, et al. Evaluation of type 2 diabetic mellitus animal models via interactions between insulin and mitogenactivated protein kinase signaling pathways induced by a high fat and sugar diet and streptozotocin. Mol Med Rep. 2018;17(4):5132-42.

37. Jahan IA, Nahar N, Mosihuzzaman M, Rokeya B, Ali L, Azad Khan AK, et al. Hypoglycaemic and antioxidant activities of Ficus racemosa Linn. Fruits. Nat Prod Res. 2009;23(4):399-408.

38. Trinder P. Determination of blood glucose using an oxidase-peroxidase system with a non-carcinogenic chromogen. J Clin Pathol. 1969;22(2):158-61.

39. Kendall FE. A simplified method for the estimation of total cholesterol in serum and demonstration of its specificity. J Biol Chem. 1952;195:357-66.

40. Fossati P, Prencipe L. Serum triglycerides determined colorimetrically with an enzyme that produces hydrogen peroxide. Clin Chem. 1982;28(10):2077-80.

41. Friedewald WT, Levy RI, Fredrickson DS. Estimation of the concentration of low-density lipoprotein cholesterol in plasma, without use of the preparative ultracentrifuge. Clin Chem. 1972;18(6):499-502.

42. Dobiásová M, Frohlich J. The plasma parameter log (TG/HDL-C) as an atherogenic index: correlation with lipoprotein particle size and esterification rate inapob-lipoprotein-depleted plasma (FERHDL). Clin Biochem. 2001;34(7):583-8.

43. Bergmeyer $\mathrm{H}$, Scheibe $\mathrm{P}$, Wahlefeld A. Optimization of methods for aspartate aminotransferase and alanine aminotransferase. Clin Chem. 1978;24(1):58-73.

44. Larsin K. Creatinine assay by a reaction-kinetic approach. Clin Chem Acta. 1972;41:209-17.

45. Haines DM, Chelack BJ. Technical considerations for developing enzyme immunohistochemical staining procedures on formalin-fixed paraffinembedded tissues for diagnostic pathology. J Vet Diagn Investig. 1991; $3(1): 101-12$

46. Afroz R, Islam N, Biswas KR, Ishika T, Rahman M, Swarna A, et al. Medicinal plants used by folk medicinal practitioners in three randomly surveyed villages of Rajbari district, Bangladesh. Am-Eur J Sustainable Agric. 2011;5(2):226-32.

47. Dua TK, Dewanjee S, Khanra R. Prophylactic role of Enhydra fluctuans against arsenic-induced hepatotoxicity via anti-apoptotic and antioxidant mechanisms. Redox Rep : Commun Free Radic Res. 2016;21 (4):147-54.

48. Satyajit DP. Natural flavonoids isolated from the leaves of Enhydra fluctuans inhibits cyclooxygenase-2 and 5-lipooxygenase inflammation in various models. Int J Res Pharmacol Pharmacotherapeut. 2012;1:65-71.

49. Yamano T, Shimizu M, Noda T. Comparative effects of repeated administration of cadmium on kidney, spleen, thymus, and bone marrow in 2-, 4-, and 8-month-old male Wistar rats. Toxicol Sci. 1998;46(2):393-402.

50. Van Campenhout K, Infante HG, Adams F, Blust R. Induction and binding of $\mathrm{Cd}$, $\mathrm{Cu}$, and $\mathrm{Zn}$ to metallothionein in carp (Cyprinus carpio) using HPLC-ICPTOFMS. Toxicol Sci. 2004;80(2):276-87.

51. Rajalakshmi M, Eliza J, Priya CE, Nirmala A, Daisy P. Anti-diabetic properties of Tinospora cordifolia stem extracts on streptozotocin-induced diabetic rats. Afr J Pharm Pharmacol. 2009;3(5):171-80.

52. Jaganathan R, Ravindran R, Dhanasekaran $\mathrm{S}$. Emerging role of adipocytokines in type 2 diabetes as mediators of insulin resistance and cardiovascular disease. Can J Diabetes. 2018:42(4):446-56 e441.

53. Vega GL, Barlow CE, Grundy SM, Leonard D, DeFina LF. Triglyceride-tohigh-density-lipoprotein-cholesterol ratio is an index of heart disease mortality and of incidence of type 2 diabetes mellitus in men. J Investig Med. 2014:62(2):345-9.

54. Bitzur R, Cohen H, Kamari Y, Shaish A, Harats D. Triglycerides and HDL cholesterol: stars or second leads in diabetes? Diabetes Care. 2009;32(suppl 2):S373-7.

55. Suanarunsawat T, Ayutthaya WDN, Songsak T, Thirawarapan S, Poungshompoo S. Antioxidant activity and lipid-lowering effect of essential oils extracted from Ocimum sanctum L. leaves in rats fed with a high cholesterol diet. J Clin Biochem Nutr. 2009;46(1):52-9

\section{Publisher's Note}

Springer Nature remains neutral with regard to jurisdictional claims in published maps and institutional affiliations.

Ready to submit your research? Choose BMC and benefit from:

- fast, convenient online submission

- thorough peer review by experienced researchers in your field

- rapid publication on acceptance

- support for research data, including large and complex data types

- gold Open Access which fosters wider collaboration and increased citations

- maximum visibility for your research: over $100 \mathrm{M}$ website views per year

At $\mathrm{BMC}$, research is always in progress.

Learn more biomedcentral.com/submissions 